\title{
P2X Receptor Trafficking in Neurons Is Subunit Specific
}

\author{
Laura K. Bobanovic, Stephen J. Royle, and Ruth D. Murrell-Lagnado \\ Department of Pharmacology, University of Cambridge, Cambridge CB2 1PD, United Kingdom
}

P2X receptors within the CNS mediate excitatory synaptic transmission and also act presynaptically to modulate neurotransmitter release. We have studied the targeting and trafficking of $\mathrm{P} 2 \mathrm{X} 4$ and $\mathrm{P} 2 \mathrm{X} 2$ receptors heterologously expressed in cultured olfactory bulb neurons. Homomeric P2X4 receptors had a punctate distribution, and many of the puncta colocalized with early endosomes. In contrast, P2X2 receptors were primarily localized at the plasma membrane. By antibody-labeling of surface receptors in living neurons, we showed that P2X4 receptors undergo rapid constitutive internalization and subsequent reinsertion into the plasma membrane, whereas P2X2

Cells regulate the number of receptor molecules at the plasma membrane. In neurons, ionotropic receptors cycle in and out of the postsynaptic membrane to regulate the strength of synaptic connections (Carroll et al., 2001; Moss and Smart, 2001; Sheng and Lee, 2001). For instance, the insertion and internalization of AMPA receptors contributes to long-term potentiation and depression, respectively (Turrigiano, 2000; Carroll et al., 2001). The rate of AMPA receptor internalization is dependent on electrical activity, activation of intracellular signaling pathways, and ligand binding (Lissin et al., 1998; Beattie et al., 2000; Ehlers, 2000; Lin et al., 2000; Man et al., 2000). The mechanism of internalization is similar to classical receptor-mediated endocytosis in being dependent on both clathrin and dynamin (Carroll et al., 1999; Marsh and McMahon, 1999; Lin et al., 2000; Man et al., 2000; Wang and Linden, 2000). Postsynaptic GABA $_{\mathrm{A}}$ receptors also cycle between the plasma membrane and endosomal compartments, and this modulates postsynaptic inhibition (Kittler et al., 2000; Moss and Smart, 2001).

We have investigated the trafficking of $\mathrm{P} 2 \mathrm{X}$ receptors gated by ATP. ATP is a mediator of fast synaptic transmission in the CNS (Khakh, 2001), but there is also evidence that $\mathrm{P} 2 \mathrm{X}$ receptors act presynaptically to modulate neurotransmitter release $(\mathrm{Gu}$ and MacDermott, 1997; Khakh and Henderson, 1998; Hugel and Schlichter, 2000). P2X receptors are nonselective cation channels with a relatively high calcium permeability at the resting membrane potential, so P2X-mediated calcium influx in the presynaptic terminal could modulate the release of neurotransmitter. P2X receptors comprise a family of seven distinct subunits that can form homo- or hetero-oligomeric assemblies (Torres et al., 1999;

Received Dec. 17, 2001; revised Feb. 8, 2002; accepted March 12, 2002.

This work was supported by the Biotechnology and Biological Sciences Research Council. We thank Dr. F. Araujo for help in engineering extracellular epitopes. We also thank Dr. J. M. Edwardson for anti-synaptobrevin and dynamin constructs, Dr. J. P. Luzio for anti-lgp110, and Dr. P. Thorn for anti-calreticulin. Finally, we thank Drs. L. Lagnado and M. J. Schell for critically reading this manuscript.

Correspondence should be addressed to Ruth D. Murrell-Lagnado, Department of Pharmacology, Tennis Court Road, University of Cambridge, Cambridge CB2 1PD, UK. E-mail: rdm1003@cam.ac.uk.

Copyright (C) 2002 Society for Neuroscience $\quad 0270-6474 / 02 / 224814-11 \$ 15.00 / 0$ receptors were not regulated in such a way. The internalization of P2X4 receptors was dynamin-dependent, and the binding of ATP enhanced the basal rate of retrieval in a $\mathrm{Ca}^{2+}$-independent manner. The presence of the $\mathrm{P} 2 \mathrm{X} 4$ subunit in a P2X $4 / 6$ heteromer governed the trafficking properties of the receptor. P2X receptors acted presynaptically to enhance the release of glutamate, suggesting that the regulated cycling of P2X4containing receptors might provide a mechanism for modulation of synaptic transmission.

Key words: P2X; dynamin; endocytosis; recycling; presynaptic; trafficking; heteromer; ATP; ionotropic receptor

Khakh et al., 2001b). Among the P2X receptor subunits expressed in the brain, $\mathrm{P} 2 \mathrm{X} 2, \mathrm{P} 2 \mathrm{X} 4$, and $\mathrm{P} 2 \mathrm{X} 6$ are predominant and have an overlapping regional and cellular distribution pattern (Collo et al., 1996; Lê et al., 1998; Kanjhan et al., 1999; Rubio and Soto, 2001). Immunocytochemical studies have shown that P2X subunits are present on the soma and dendrites of postsynaptic neurons as well as on presynaptic terminals (Vulchanova et al., 1997; Lê et al., 1998; Kanjhan et al., 1999).

Compared with ionotropic glutamate and $\mathrm{GABA}_{\mathrm{A}}$ receptors, very little is known about the targeting or trafficking of neuronal $\mathrm{P} 2 \mathrm{X}$ receptors. Recently, the $\mathrm{P} 2 \mathrm{X} 1$ receptor in smooth muscle and a green fluorescent protein (GFP)-tagged $\mathrm{P} 2 \mathrm{X} 1$ receptor expressed in human embryonic kidney 293 (HEK293) cells, have been shown to internalize and recycle in response to agonist application (Dutton et al., 2000; Li et al., 2000; Ennion and Evans, 2001). In this study we have compared the trafficking of two neuronal P2X receptors, P2X2 and P2X4, heterologously expressed in cultured olfactory bulb (OB) neurons. The olfactory bulb has particularly high P2X4 immunoreactivity (Lê et al., 1998) and also expresses P2X2 and P2X6 (Collo et al., 1996; Kanjhan et al., 1999). We find that P2X4 and P2X2 receptor levels at the plasma membrane are regulated in distinct manners: P2X4 receptors undergo rapid constitutive internalization and subsequent reinsertion into the plasma membrane, whereas surface P2X2 receptors are more stable. The properties of the P2X4 receptor determine the trafficking of heteromeric receptors. Activation of $\mathrm{P} 2 \mathrm{X}$ receptors enhanced synaptic glutamate release, suggesting that the regulated cycling of P2X4-containing receptors might provide a mechanism for modulation of synaptic transmission.

\section{MATERIALS AND METHODS}

Cell culture. Primary cultures of $\mathrm{OB}$ neurons were prepared from 3- to 4-d-old Wistar rats, using a modified method for culturing hippocampal neurons (Koizumi et al., 1999). Briefly, after papain dissociation (20 $\mathrm{U} / \mathrm{ml}$; Worthington, Freehold, NJ), cells were plated onto poly-D-lysinecoated $(50 \mu \mathrm{g} / \mathrm{ml})$ glass coverslips and grown in Neurobasal medium supplemented with B27, $0.5 \mathrm{~mm}$ L-glutamine, $0.1 \mathrm{~mm}$ l-serine, $1 \mathrm{~mm} \mathrm{Na}$ pyruvate, and $100 \mathrm{U} / \mathrm{ml}$ penicillin-streptomycin at $37^{\circ} \mathrm{C}$ and $5 \% \mathrm{CO}_{2}$. 
Initial plating density was $6.7 \mathrm{~cm}^{2}$ per OB. For the first $3 \mathrm{~d}$ of growth, culturing medium also included $10 \%$ horse serum. Serum-free medium containing cytosine arabinoside (ARA-C; $2 \mu \mathrm{M}$ ) was subsequently renewed every $3 \mathrm{~d}$.

HEK293 cells were maintained in DMEM (NUT.MIX.F12) containing $10 \%$ fetal bovine serum (FBS) and $100 \mathrm{U} / \mathrm{ml}$ penicillin-streptomycin at $37^{\circ} \mathrm{C}$ and $5 \% \mathrm{CO}_{2}$.

DNA constructs. Initially, two $\mathrm{P} 2 \mathrm{X} 4$ constructs were generated with GFP at either the $\mathrm{N}$ or $\mathrm{C}$ terminus. However, fusing GFP to the $\mathrm{N}$ terminus of P2X4 (GFP-P2X4) dramatically inhibited expression in $\mathrm{Xe}$ nopus oocytes and in $\mathrm{OB}$ neurons, and therefore this construct was not studied further. To generate cDNAs encoding P2X2, P2X4, and P2X6 with GFP fused to the $\mathrm{C}$ terminus, the rat cDNAs (kind gifts from Prof. P. P. A. Humphrey, Cambridge, UK) were amplified by PCR using oligonucleotide primers designed to introduce a Kozak (1987) initiation sequence, to remove the stop codon and to introduce NheI and SacII (P2X4) or EcoR I and SacII (P2X2 and P2X6) sites at the 5' and $3^{\prime}$ ends, respectively. Amplification products were then cloned into the pEGFP-N1 vector (Clontech, Palo Alto, CA).

For expression of either wild-type or epitope-tagged $\mathrm{P} 2 \mathrm{X}$ receptors, the coding sequences of $\mathrm{P} 2 \mathrm{X} 2$ and $\mathrm{P} 2 \mathrm{X} 4$ were amplified to reintroduce the stop codon and an $\mathrm{XbaI}$ site. The subcloning of these fragments excised the coding sequence of GFP. Epitope AU5 (TDFYLK) was substituted into P2X4 at position 76 (TSQLGF) by two-step PCR. Epitope FLAG (DYDDDDK) was inserted into P2X2 between D78 and K79 (Stoop et al., 1998). The sequences of all amplified regions were verified by automated DNA sequencing. The sequences of all primers used are available on request.

Hemagglutinin (HA)-tagged human dynamin -1 and dynamin $-1(\mathrm{~K} 44 \mathrm{~A})$ cDNAs in pcDNA3 expression vector were kind gifts from Dr. J. M. Edwardson (Cambridge, UK).

Cell transfection. OB neurons were transfected at 10-21 d in vitro (DIV) using a modified calcium phosphate method (Xia et al., 1996). Briefly, precipitates were formed by adding $6 \mu \mathrm{g}$ of plasmid DNA to 60

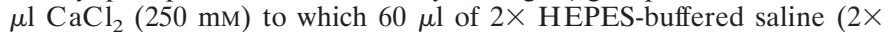
HBS in mM: $274 \mathrm{NaCl}, 10 \mathrm{KCl}, 1.4 \mathrm{Na}_{2} \mathrm{HPO}_{4}, 15$ D-glucose, 42 HEPES, $\mathrm{pH}$ 7.07) was added dropwise. Precipitate $(55 \mu \mathrm{l} / 21$-mm-diameter well $)$ was added to the cells whose culturing medium was replaced with transfection buffers (in mM: $10 \mathrm{MgCl}_{2}, 10 \mathrm{HEPES}, 0.5 \mathrm{~L}$-glutamine, and $100 \mathrm{U} / \mathrm{ml}$ penicillin-streptomycin in Neurobasal media, $\mathrm{pH}$ 7.2). Optimization of the volume of precipitate and $\mathrm{pH}$ of HBS, removal of endotoxins from DNA solutions, and duration of the incubation $(2 \mathrm{hr})$ resulted in low levels of toxicity and transfection efficiency of $>5 \%$. After transfection the neurons were washed with transfection buffer and then kept in the previous culturing medium for up to $2 \mathrm{~d}$. For cotransfection experiments, equal amounts of DNA were used to a total $6 \mu \mathrm{g}$.

HEK293 cells were plated onto poly-D-lysine-treated coverslips $(2.4 \times$ $10^{-4}$ cells $/ \mathrm{cm}^{2}$ ) and transfected $12 \mathrm{hr}$ later using the same method with slight modifications. The amount of DNA used to form precipitate was 3 $\mu \mathrm{g}$ (in $100 \mu \mathrm{l} \mathrm{CaCl} / 100 \mu \mathrm{l} 2 \times \mathrm{HBS}$ ). Precipitate $(100 \mu \mathrm{l} / 21-\mathrm{mm}-$ diameter well) was added, and cells were kept with precipitate for $6 \mathrm{hr}$. For cotransfection experiments, equal amounts of DNA were used, and controls for lone expression had half the total DNA. We included $0.5 \mu \mathrm{g}$ of pEGFP-N1 vector for coexpression of GFP with nonfluorescent constructs.

Electrophysiological recordings. Standard whole-cell recordings (Hamill et al., 1981) were performed at room temperature (RT) using an Axopatch 200A amplifier (Axon Instruments, Foster City, CA). Patch pipettes (3-8 $\mathrm{M} \Omega$ ) were pulled from thick-walled borosilicate glass (GC150F-10; Harvard Apparatus, Holliston, MA) and filled with solution containing (in mM): $125 \mathrm{~K}$-gluconate, $1 \mathrm{MgCl}_{2}$, and $10 \mathrm{HEPES}, \mathrm{pH}$ 7.3. The extracellular solution was composed of (in mM): $140 \mathrm{NaCl}, 5$ $\mathrm{KCl}, 2 \mathrm{CaCl}_{2}, 1 \mathrm{MgCl}_{2}, 10 \mathrm{D}$-glucose, and 10 HEPES, pH 7.3. ATPevoked responses were measured at $-60 \mathrm{mV}$ in neurons and at $-50 \mathrm{mV}$ in HEK293 cells.

To visualize cells expressing P2X receptors without a GFP tag, cells were cotransfected with GFP. Cells expressing GFP or GFP-tagged P2X subunits were observed under a microscope with an epifluorescence attachment (Nikon, Tokyo, Japan). Untransfected cells and cells expressing GFP alone were found to have no inward current in response to application of ATP. ATP was applied locally using a Picospritzer II (Parker Instrumentation, Fairfield, NJ). To ensure delivery of drug, $0.05 \%(\mathrm{w} / \mathrm{v})$ fast green was used (local applications of $1 \%$ fast green evoked no response).

The effects of ATP on the frequency of miniature postsynaptic cur- rents (mPSCs) were measured in neurons that were $>14$ DIV before transfection and that displayed spontaneous activity, indicating that they had formed synaptic connections. Whole-cell recordings were made from untransfected neurons that neighbored transfected neurons. Pairs of neurons were chosen on the basis that they were in close proximity but not immediately adjacent to one another. ATP was applied where their processes appeared to be in intimate contact. As a control, pairs of untransfected neurons were chosen, and ATP was applied to see if activation of endogenous receptors could elicit a change in MPSC frequency. In all cases, neurons were held at $-40 \mathrm{mV}$, so that miniature EPSCs (mEPSCs) and miniature IPSCs (mIPSCs) appeared as inward and outward currents, respectively. The extracellular solution contained tetrodotoxin (TTX; $1 \mu \mathrm{M})$. In some experiments either 6-cyano-7nitroquinoxaline-2,3-dione (CNQX; $10 \mu \mathrm{M})$ or bicuculline $(20 \mu \mathrm{M})$ were coapplied with ATP to block fast glutamatergic and GABAergic transmission, respectively.

Whole-cell currents were low-pass filtered at $2 \mathrm{kHz}$ and digitized at 10 $\mathrm{kHz}$. Acquisition was performed using Heka (Lambrecht, Germany) Pulse 8.30, and data were subsequently analyzed using IgorPRO 3.14. Concentration-effect curves were fitted to the Hill equation. The frequency of mEPSC was determined during $20 \mathrm{sec}$ time interval before and during ATP application. Events were selected manually on the basis of their rapid rise time and exponential decay kinetics.

Immunocytochemistry. Cells were fixed in $3 \%$ paraformaldehyde and $4 \%$ sucrose in PBS (in mM: $1.5 \mathrm{NaH}_{2} \mathrm{PO}_{4}, 8 \mathrm{Na}_{2} \mathrm{HPO}_{4}$, and $145 \mathrm{NaCl}, \mathrm{pH}$ 7.3 ) for $10 \mathrm{~min}$ at $4^{\circ} \mathrm{C}$. If required, permeabilization was done using $0.1 \%$ Triton X-100 in PBS for $10 \mathrm{~min}$ at $4^{\circ} \mathrm{C}$. Nonspecific sites were blocked using PBS containing 4\% normal goat serum and 3\% bovine serum albumin (blocking buffer). Antibodies were diluted to their final concentration in blocking buffer. Primary antibodies were applied for $2 \mathrm{hr}$ at RT. Cells were rinsed once in blocking buffer and three times for $5 \mathrm{~min}$ with PBS, and then secondary antibodies were applied for $2 \mathrm{hr}$ at RT. Finally, cells were washed five times for $5 \mathrm{~min}$ with PBS and mounted onto slides with Vectashield (Vector Laboratories, Burlingame, CA) as a mounting medium.

Representative images of immunocytochemical experiments were obtained using a Bio-Rad (Hercules, CA) MRC1024, Zeiss Axiovert LSM 510 or Perkin-Elmer UltraVIEW confocal microscope, with $60 \times, 63 \times$, or $100 \times$ oil immersion objectives, respectively. Fluorescein isothiocyanate (FITC)-GFP, Cy3- tetramethylrhodamine isothiocyanate (TRITC), and Cy5 were excited at 488, 543, and $633 \mathrm{~nm}$, respectively. When either two or three fluorophores were visualized, separate excitation and collection was used to minimize bleedthrough.

Live-labeling immunofluorescence protocols. The basic protocol for livelabeling was as follows: cells were incubated with the lysosomal protease inhibitor leupeptin $(100 \mu \mathrm{g} / \mathrm{ml})$, for $1 \mathrm{hr}$ before incubation with antiAU5, and leupeptin was included throughout all steps. Anti-AU5 was applied for $30 \mathrm{~min}$ at $37^{\circ} \mathrm{C}$ in serum- and supplement-free culture medium as a buffer. Cells were then washed five times and fixed in PFA. To detect AU5-labeled receptors at the surface, fixed nonpermeabilized neurons were stained with an anti-mouse Cy3-conjugated secondary for $2 \mathrm{hr}$ at RT. Cells were then washed five times in PBS, permeabilized with $0.1 \%$ Triton $\mathrm{X}-100$, and stained with an anti-mouse FITC-conjugated secondary for $2 \mathrm{hr}$ at RT, to visualize prelabeled internalized receptors.

To estimate the time course of receptor internalization, neurons were incubated with anti-AU5 for $10,20,30$, or $60 \mathrm{~min}$ at $37^{\circ} \mathrm{C}$. After fixation, cells were double-labeled using two different methods. First, to determine the ratio between surface receptors and the total receptor population, nonpermeabilized cells were stained with an anti-mouse Cy5conjugated secondary. After permeabilization, neurons were stained for total receptor using anti-P2X4 and an anti-rabbit Cy3-conjugated secondary. Second, to determine the ratio between AU5-labeled receptors (surface and internalized) and the total receptor population, neurons were permeabilized before staining with anti-mouse Cy5-conjugated secondary.

For recycling experiments, HEK293 cells expressing P2X4(AU5) were incubated with anti-AU5 as described above. Cells were washed five times in buffer before being gradually cooled to $4^{\circ} \mathrm{C}$ to inhibit trafficking. Cells were then incubated with nonfluorescent anti-mouse antibody for 1 $\mathrm{hr}$ at $4^{\circ} \mathrm{C}$ to block AU5-labeled receptors at the surface. Cells were either fixed at this point or returned to $37^{\circ} \mathrm{C}$ for $15 \mathrm{~min}$ to allow internalized receptors to recycle back to the surface. Cells were then fixed, and the surface and internalized receptors were detected with Cy3- and FITCconjugated secondary antibodies, respectively.

To examine the effects of ATP and extracellular $\mathrm{Ca}^{2+}$ on receptor 
internalization, neurons were labeled as above, washed five times in buffer, and subsequently incubated for $15 \mathrm{~min}$ at $37^{\circ} \mathrm{C}$ with or without ATP $(100 \mu \mathrm{M})$ in either a control solution or in a $\mathrm{Ca}^{2+}$-free solution. The control solution contained (in $\mathrm{mM}$ ): $140 \mathrm{NaCl}, 5 \mathrm{KCl}, 2 \mathrm{CaCl}_{2}, 1 \mathrm{MgCl}_{2}$, 10 D-glucose, and $10 \mathrm{HEPES}, \mathrm{pH}$ 7.3. For $\mathrm{Ca}^{2+}$-free solution, calcium was omitted, and $1 \mathrm{~mm}$ EGTA was added. Prelabeled receptors at the surface and internalized receptors were detected as above. The effect of agonist on P2X2-GFP-expressing neurons was assessed by incubating transfected neurons in control solution for $15 \mathrm{~min}$ at RT with either ATP or 2-methylthioadenosine $5^{\prime}$-triphosphate (2meSATP; $\left.100 \mu \mathrm{M}\right)$. In some experiments, before ATP application, P2X2-GFP-expressing neurons were preincubated for $10 \mathrm{~min}$ with pyridoxal-phosphate-6-azophenyl-2', $4^{\prime}$-disulphonic acid (PPADS; $\left.10 \mu \mathrm{M}\right)$ or suramin $(100 \mu \mathrm{M})$. Cultures were subsequently fixed and stained for microtubule-associated protein-2 (MAP-2).

Image analysis. Fluorescence was visualized using a Zeiss Axiovert LSM510 confocal microscope, using $63 \times$ oil immersion objective. For FITC-Cy3 anti-AU5 double labeling, FITC and Cy3 were excited at 7 and $60 \%$ of 488 and 543 nm laser power, respectively. For Cy3-Cy5 anti-AU5 and anti-P2X4 double labeling, Cy3 and Cy5 were excited at 4 and $70 \%$ of 543 and $633 \mathrm{~nm}$ laser power, respectively. For the P2X4(AU5)/dynamin-1 conditions, FITC and Cy3 were excited at 7 and $49 \%$ of 488 and $543 \mathrm{~nm}$ laser power, respectively. In P2X4(AU5)/ dynamin-1(K44A) conditions, there was greater P2X4(AU5) labeling; accordingly, we reduced both laser powers to $1 / 4(1.75$ and $12.25 \%)$. A series of confocal sections (1 $\mu \mathrm{m}$ thickness) were taken of immunostained neurons at $0.14 \mu \mathrm{m} /$ pixel. For individual experiments, images for all conditions were analyzed using identical acquisition parameters.

Tagged image file format (TIFF) images were imported into NIH Image 1.62, and the cells outlined and mean pixel values for each channel were obtained for a region over the cell soma. The images were selected so that confocal plane was focused on the middle of the cell to exclude signal from the top and bottom of the cell. Pixel values were on an 8-bit scale $\left(2^{8}=256 ; 0-255\right)$. For time course experiments, ratios of either surface versus total expressed receptor (Cy5 vs $\mathrm{Cy} 3$ ) or labeled versus total expressed receptors ( $\mathrm{Cy} 5$ vs $\mathrm{Cy} 3)$ were obtained.

For recycling and internalization experiments, red (Cy3) or green (FITC) fluorescence intensities indicative of surface or internalized receptors were divided by total labeled (red plus green) fluorescence intensities, respectively. Units of surface or internalized receptor were measured as red per total or green per total fluorescence normalized to untreated controls. For dynamin experiments, the ratio of surface versus total expressed receptor (Cy3 vs FITC) was obtained. Experiments were repeated at least two times, and each time, data were analyzed from four to six cells from two separate coverslips. Within each experiments the data were normalized to control cells. The $n$ value given refers to the number of cells analyzed. All data are presented as the mean \pm SEM. Histograms and plots were done using IgorPRO 3.14 software.

Statistical analyses were performed with Student's unpaired $t$ test or ANOVA with Bonferroni's post hoc comparison using InStat software (version 2.01; GraphPad Software Inc., San Diego, CA). All results are given as mean $\pm \mathrm{SEM}$, and levels of statistical significance are * $p<0.05$, $* * p<0.01$, and $* * * p<0.001$.

Antibodies and reagents. The following primary antibodies were used: affinity-purified anti-AU5 (5 $\mathrm{g} / \mathrm{ml}$; Babco, Richmond, CA), anti-FLAG M2 (2 $\mu \mathrm{g} / \mathrm{ml}$; Sigma, St. Louis, MO), anti-synaptobrevin (1:750; a kind gift from Dr. J. M. Edwardson, Cambridge, UK), anti-EEA-1 (2.5 $\mu \mathrm{g} / \mathrm{ml}$; Transduction Laboratories, Lexington, KY), anti-MAP-2 (1:250; Roche Products, Hertforshire, UK), and anti-hemagglutinin $(0.8 \mu \mathrm{g} / \mathrm{ml}$; Roche) all mouse monoclonal; anti-P2X4 (6 $\mu \mathrm{g} / \mathrm{ml}$; Alomone Labs, Jerusalem, Israel), anti-P2X2 (0.6 $\mu \mathrm{g} / \mathrm{ml}$; Alomone), anti-lgp110 (1:250; a kind gift from Dr. J. P. Luzio, Cambridge, UK), and anti-calreticulin (1:200; a kind gift from Dr. P. Thorn, Cambridge, UK) all rabbit polyclonal. FITC-, Cy3-, TRITC-, and Cy5-conjugated goat anti-mouse, anti-rabbit (1:250), or nonfluorescent goat anti-mouse IgG (1:100) were used as secondary antibodies (Jackson ImmunoResearch, West Grove, PA).

TTX (5 mM stock solution in ethanol), CNQX (50 mM stock solution in DMSO), bicuculline (80 mM stock solution in DMSO), PPADS, and leupeptin $(10 \mathrm{mg} / \mathrm{ml})$ were purchased from Tocris Cookson (Bristol, UK). Unless otherwise stated, all other reagents were obtained from Sigma or Invitrogen (San Diego, CA).
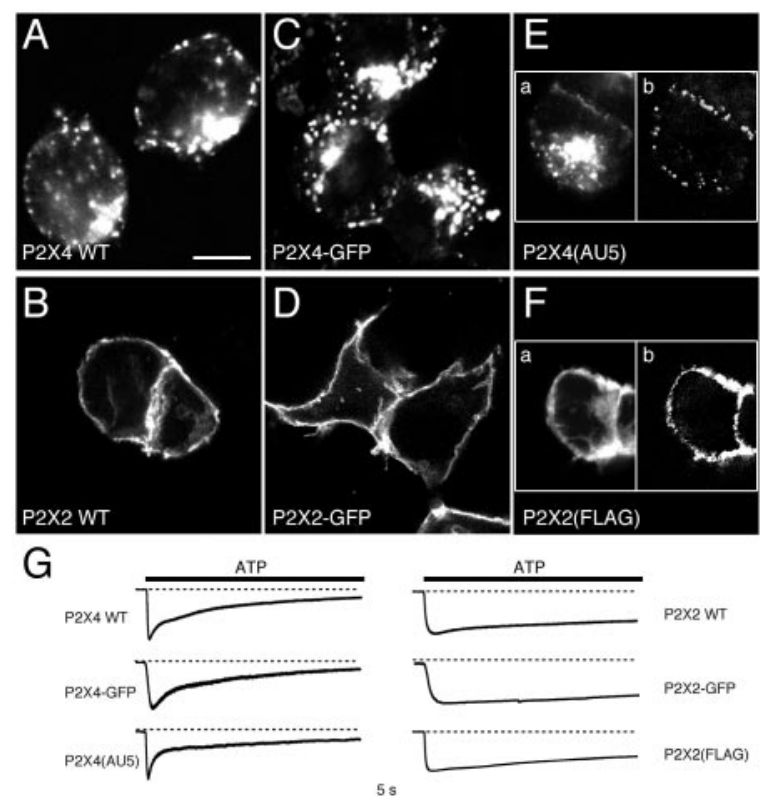

ATP

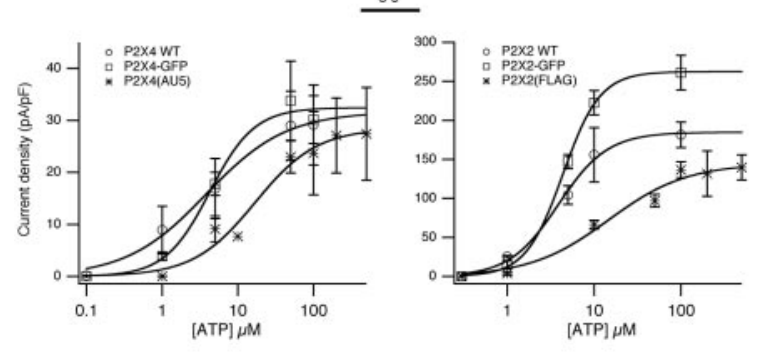

Figure 1. Subcellular distribution and functional properties of P2X constructs in HEK293 cells. $A-F$, The subcellular distribution of P2X4 WT $(A), \mathrm{P} 2 \mathrm{X} 4-\mathrm{GFP}(C), \mathrm{P} 2 \mathrm{X} 4(\mathrm{AU} 5)(E), \mathrm{P} 2 \mathrm{X} 2 \mathrm{WT}(B), \mathrm{P} 2 \mathrm{X} 2-\mathrm{GFP}(D)$, and $\mathrm{P} 2 \mathrm{X} 2(\mathrm{FLAG})(F)$ receptors in HEK293 cells. Cells expressing untagged receptors were stained using anti-P2X $4 / \mathrm{Cy} 3$ or anti-P $2 \mathrm{X} 2 / \mathrm{Cy} 3$. Cells expressing P2X4(AU5) were stained using anti-AU5/Cy3 before ( $E$, left panel $)$ and anti-P2X4/FITC after permeabilization. Cells expressing P2X2(FLAG) were stained using anti-FLAG/Cy3 before ( $F$, left panel) and anti-P2X2/FITC after permeabilization. Scale bar, $10 \mu \mathrm{m}$. $G$, Concentration-effect curves for ATP and representative traces showing ATPevoked whole-cell currents for P2X4 (left) and P2X2 (right) constructs used in this study. ATP-evoked peak currents shown are normalized to compare the time course of desensitization. Calculated $\mathrm{EC}_{50}$ values were 3.8, 4.2, and $17 \mu \mathrm{M}$ for P2X4 WT, P2X4-GFP, and P2X4(AU5), respectively. Calculated $\mathrm{EC}_{50}$ values for P2X2 WT, P2X2-GFP, and P2X2(FLAG) were 3.9, 4.4, and $14.6 \mu \mathrm{M}$, respectively $(n=3-7$ cells for each concentration).

\section{RESULTS}

\section{Subunit-dependent trafficking of P2X receptors expressed in HEK293 cells}

To allow visualization of $\mathrm{P} 2 \mathrm{X}$ receptor trafficking in live cells, we introduced AU5 and FLAG epitopes into the extracellular loops of P2X4 and P2X2, respectively, and we separately tagged both subunits with GFP at their C terminus. Wild-type and tagged receptors were expressed in HEK293 cells to compare their distributions and functional properties. The distributions of the tagged receptors were very similar to their wild-type counterparts (Fig. $1 A-F$ ). The $\mathrm{P} 2 \mathrm{X} 4$ receptors all had a punctate distribution, and confocal images indicated that most of the clusters were intracellular (Fig. 1A,C,E). In contrast, $\mathrm{P} 2 \mathrm{X} 2$ receptors were more uniformly distributed and predominantly at the periphery of the cell (Fig. 1B,D,F). Using epitope-tagged receptors, those at 

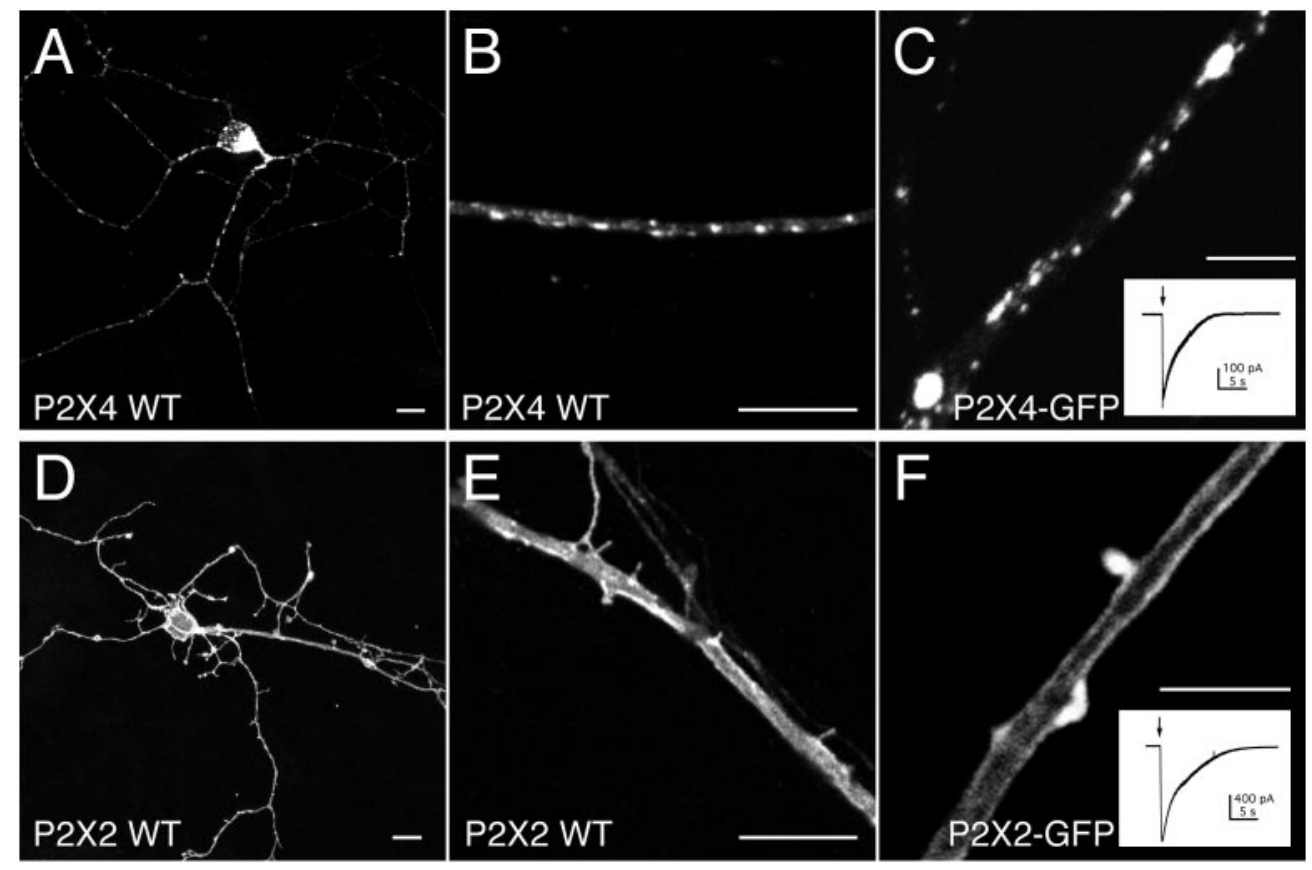

Figure 2. Subcellular distribution of heterologously expressed $\mathrm{P} 2 \mathrm{X}$ receptors in neurons. Confocal images of heterologously expressed $\mathrm{P} 2 \mathrm{X} 4 \mathrm{WT}(A, B)$, P2X4-GFP $(C), \mathrm{P} 2 \mathrm{X} 2 \mathrm{WT}(D, E)$, and P2X2-GFP $(F)$ receptors in mature OB neurons. Insets, $C, F$, Example traces of whole-cell currents evoked by a $0.5 \mathrm{sec}$ application of ATP $(100 \mu \mathrm{M})$. Cells expressing untagged receptors were stained using anti-P2X4/Cy3 and antiP2X2/Cy3, respectively. Scale bars: $A$, $B, D, E, 10 \mu \mathrm{m} ; C, F, 5 \mu \mathrm{m}$.

the surface were labeled in addition to the total receptor population. For P2X2(FLAG), there was considerable overlap between the two labels, whereas for P2X4(AU5), the majority of puncta were not at the surface (Fig. 1E,F).

Using whole-cell patch clamp we compared the functional responses to ATP for all six receptors (Fig. 1G). The time courses were similar for the tagged receptor currents and their wild-type counterparts. P2X2-GFP and P2X2(FLAG) receptor currents were slowly desensitizing, whereas P2X4-GFP, P2X4(AU5) and wild-type P2X4 receptor currents desensitized more rapidly. For each of the three $\mathrm{P} 2 \mathrm{X} 4$ receptors, the decay was biphasic, and there was no significant difference in the values of the fast and slow time constants $\left(\tau_{\text {fast }}=1.1 \pm 0.4 \mathrm{sec}, 1.1 \pm 0.3 \mathrm{sec}, 1.4 \pm 0.4\right.$ sec, and $\tau_{\text {slow }}=9.5 \pm 3.1 \mathrm{sec}, 8.9 \pm 0.5 \mathrm{sec}, 11.1 \pm 3.0 \mathrm{sec} ; n=$ 4 for P2X4, P2X4-EGFP, and P2X4(AU5), respectively). P2X4 and $\mathrm{P} 2 \mathrm{X} 4-\mathrm{GFP}$ currents also had a similar $\mathrm{EC}_{50}$ values and peak current density. However, for P2X4(AU5) and P2X2(FLAG) receptors, the introduction of epitopes just downstream of the first transmembrane regions produced a shift in the concentration-effect relationship to higher concentrations of ATP. The peak current density for P2X2-GFP was also 1.4-fold higher than for the wild-type receptor. We conclude that tagging the receptors does not fundamentally disrupt their functional expression and that the trafficking of $\mathrm{P} 2 \mathrm{X} 2$ and $\mathrm{P} 2 \mathrm{X} 4$ receptors in HEK293 cells is different.

\section{Constitutive endocytosis of P2X4 receptors expressed in OB neurons}

We next compared the distribution of wild-type and tagged P2X2 and $\mathrm{P} 2 \mathrm{X} 4$ receptors in dissociated $\mathrm{OB}$ neurons that were cultured for between 1 and 3 weeks. These neurons showed no response to ATP $(n=129)$ and were devoid of endogenous P2X2 or P2X4 immunoreactivity. Both $\mathrm{P} 2 \mathrm{X} 2$ and $\mathrm{P} 2 \mathrm{X} 4$ receptors were expressed throughout the cell (Fig. 2A,D). Similar to HEK293 cells, the principal difference between the two subtypes was that P2X4 receptors were clustered into discrete puncta, whereas $\mathrm{P} 2 \mathrm{X} 2$ receptors were not (Fig. $2 B, C, E, F$ ). This difference was apparent as early as $4 \mathrm{hr}$ after transfection when protein expression was far lower. We also transfected cultured hippocampal neurons from embryonic rats and obtained the same result: P2X 4 was punctate and intracellular, whereas $\mathrm{P} 2 \mathrm{X} 2$ was uniform and at the plasma membrane (results not shown). In P2X2-transfected OB neurons, two rails of fluorescence were apparent along large dendrites, suggestive of receptors at the plasma membrane (Fig. 2E,F). Whole-cell ATP-evoked peak current densities were $25.5 \pm 5.2$ $\mathrm{pA} / \mathrm{pF}(n=15)$ and $285.8 \pm 51.4 \mathrm{pA} / \mathrm{pF}(n=6)$ for OB neurons transfected with P2X4-GFP and P2X2-GFP, respectively.

Many of the P2X4-GFP fluorescent puncta within the processes colocalized with early endosomal antigen-1 (EEA -1), a marker for early endosomes (Fig. $3 A$ ). There was also correspondence between puncta in the soma and proximal dendrites and a marker for lysosomes (lgp110) (Fig. 3B). In contrast, there was no colocalization between $\mathrm{P} 2 \mathrm{X} 2$ receptors and either EEA-1 or lgp110 (data not shown). Consistent with the presence of $\mathrm{P} 2 \mathrm{X} 4$ receptors in early endosomes, we were able to directly visualize the internalization of surface-labeled $\mathrm{P} 2 \mathrm{X} 4(\mathrm{AU} 5)$ receptors in live neurons. After a $30 \mathrm{~min}$ incubation with anti-AU5 at $37^{\circ} \mathrm{C}$, surface receptors were in discrete clusters around the soma and along the processes, and internalized receptors were present throughout the neuron (Fig. 3C). Similar experiments were performed with neurons transfected with P2X2(FLAG). Consistent with the lack of endosomal P2X2 receptors, the internalization of P2X2(FLAG) was negligible, whereas expression at the surface was high (Fig. 3D).

We estimated the time course of P2X4(AU5) receptor internalization in neurons, by incubating cells with anti-AU5 for different periods of time. After fixing neurons, either the total population of AU5-labeled receptors (labeled AU5) or just the surface receptors (surface AU5) were detected. In both cases the total receptor population was independently labeled using antiP2X4 (total P2X4). As shown in Figure $4 A$, surface AU5 fluorescence did not change significantly between 10 and $60 \mathrm{~min}$. Therefore, we assume that the increase in labeled AU5 fluorescence over time represents the rate at which AU5-labeled receptors were internalized. The time course was fitted by a single exponential curve with a time constant of $21 \mathrm{~min}$. The binding of 


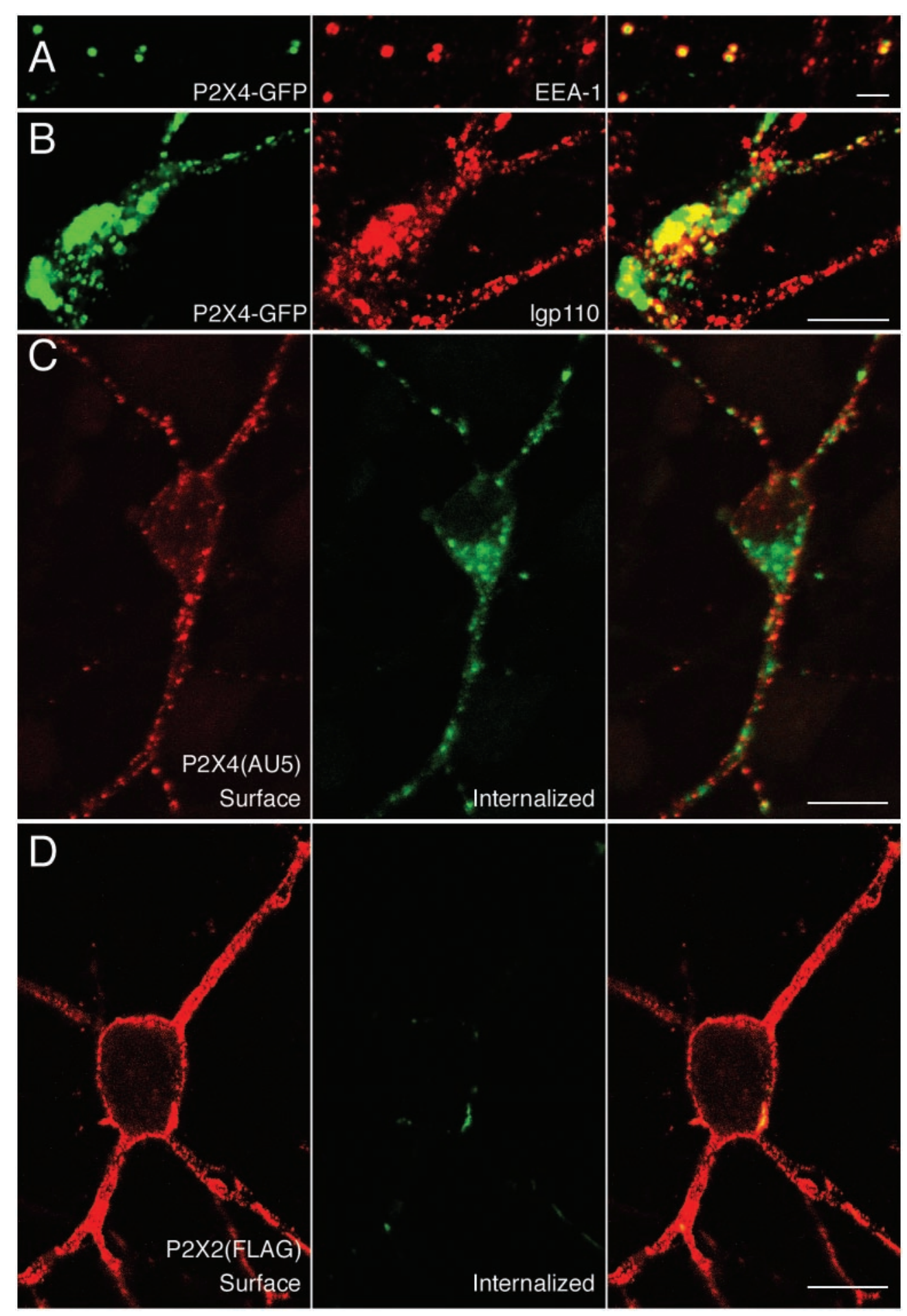

Figure 3. $\mathrm{P} 2 \mathrm{X} 4$, but not $\mathrm{P} 2 \mathrm{X} 2$, receptors are constitutively internalized. In distal processes, P2X4-GFP puncta colocalize with anti-EEA1/Cy3 staining $(A)$, and costaining with anti-lgp110/Cy3 shows that large accumulations of $\mathrm{P} 2 \mathrm{X} 4-$ GFP in the cell soma are within lysosomes $(B)$. Live-labeling of P2X4(AU5) $(C)$ and $\mathrm{P} 2 \mathrm{X} 2$ (FLAG) $(D)$ receptors for 30 min at $37^{\circ} \mathrm{C}$ with anti-AU5 and antiFLAG, respectively. In $C$ and $D$, cell surface (left) and internalized (middle) receptors were visualized using $\mathrm{Cy} 3$ conjugated and FITC-conjugated secondary antibodies, before and after permeabilization, respectively. Overlaid images are shown on the right panels. Scale bars: $A, 2 \mu \mathrm{m} ; B-D, 10 \mu \mathrm{m}$.

the antibody did not change the surface expression of receptors in live cells. The ratio of surface AU5- to total P2X4-staining was comparable after a $60 \mathrm{~min}$ incubation with anti-AU5 at $37^{\circ} \mathrm{C}$ as compared with applying anti-AU5 after fixing cells $(0.27 \pm 0.03$; $n=5$ vs $0.25 \pm 0.08 ; n=3$, respectively).

\section{Recycling of P2X4 receptors to the surface}

In neurons, the rate at which $\mathrm{P} 2 \mathrm{X} 4$ receptors were labeled with anti-AU5 approached a plateau, suggesting that internalized receptors recycled back to the surface. We tested this directly in P2X4(AU5)-transfected HEK293 cells by blocking AU5-labeled surface receptors with a nonfluorescent secondary antibody at $4^{\circ} \mathrm{C}$ and returning cells to $37^{\circ} \mathrm{C}$ to allow receptor trafficking to continue. There was a 1.5 -fold increase in the cell surface fluorescence after $30 \mathrm{~min}$, indicating that internalized receptors had recycled back to the plasma membrane (Fig. 4B,C).

\section{Agonist-regulated internalization of $\mathrm{P} 2 \mathrm{X} 4$ receptors}

The constitutive cycling of $\mathrm{P} 2 \mathrm{X} 4$ receptors into and out of the membrane suggests a mechanism for rapidly upregulating or downregulating the functional expression of receptors. Previously it was shown that application of ATP increased the internaliza- 

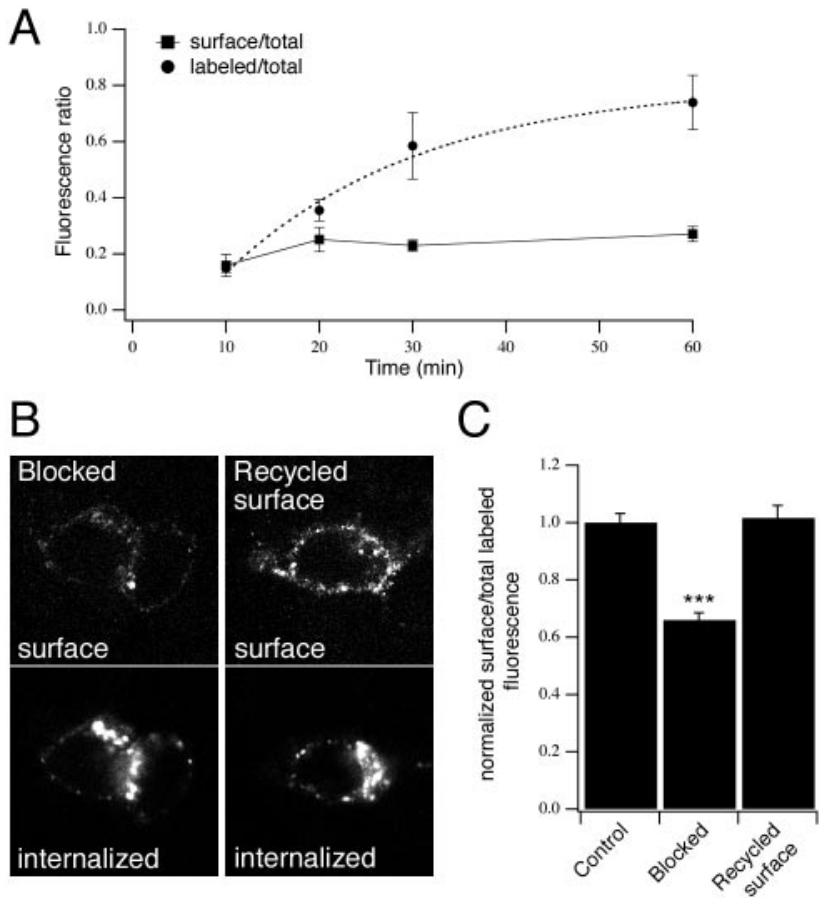

Figure 4. Cycling of $\mathrm{P} 2 \mathrm{X} 4(\mathrm{AU} 5)$ receptors to and from the surface. $A$, Time course of $\mathrm{P} 2 \mathrm{X} 4(\mathrm{AU} 5)$ constitutive internalization in neurons. Transfected neurons were labeled with anti-AU5 for different lengths of time at $37^{\circ} \mathrm{C}$. Cells were stained using secondary antibody before (surface/ total) or after (labeled/total) permeabilization and then stained for total $\mathrm{P} 2 \mathrm{X} 4$ receptor. Fluorescence ratios are shown plotted against antibody incubation time. The time course of labeling is described by a single exponential ( $\tau=21 \mathrm{~min} ; n=4-7$ neurons for each time point). $B, C$, Internalized P2X4(AU5) receptors recycle back to the plasma membrane. Representative confocal images used for analysis show an increase in $\mathrm{P} 2 \mathrm{X} 4(\mathrm{AU} 5)$ receptors recycled to the cell surface $(B)$. Histogram $(C)$ shows the surface fluorescence as a fraction of total (surface plus internalized) fluorescence, normalized to Control cells that were fixed immediately after a $30 \mathrm{~min}$ incubation with anti-AU5. Blocked represents cells that were fixed immediately after incubating cells with a nonfluorescent secondary antibody at $4^{\circ} \mathrm{C}$. Recycled surface represents cells that were returned to $37^{\circ} \mathrm{C}$ for $15 \mathrm{~min}$ after blocking. Surface and internalized receptors were detected before and after permeabilization using $\mathrm{Cy} 3$ - and FITC-conjugated secondary antibodies, respectively ( $n=14-22$ neurons for each condition).

tion of smooth muscle P2X1 receptors (Ennion and Evans, 2001). We therefore tested the effects of ATP on P2X4 trafficking in neurons by live labeling AU5-tagged receptors followed by incubation with or without ATP. A 15 min incubation with $100 \mu \mathrm{M}$ ATP caused an $\sim 60 \%$ increase in the fraction of P2X4(AU5) receptors that were internalized. Removing external $\mathrm{Ca}^{2+}$ had no effect on basal or ATP-induced internalization, indicating that the effects of ATP binding were not mediated by calcium influx (Fig. 5A,B). We used the same approach to look at the effects of ATP on the internalization of surface P2X2(FLAG) receptors. After a 15 min incubation with ATP, there was no change in the proportion of $\mathrm{P} 2 \mathrm{X} 2$ (FLAG) receptors that were internalized (Fig. 5C). Thus, ATP binding promotes the internalization of $\mathrm{P} 2 \mathrm{X} 4$ but not $\mathrm{P} 2 \mathrm{X} 2$ receptors.

In a previous study, P2X2-GFP receptors expressed in hippocampal neurons were reported to redistribute within the membrane in response to ATP (Khakh et al., 2001a). To examine the redistribution of receptors, we imaged $\mathrm{P} 2 \mathrm{X} 2-\mathrm{GFP}$-transfected neurons in real time before and after application of ATP. Within $<1$ min after application of either 10 or $100 \mu \mathrm{M}$ ATP, we ob- served a beading effect in which clusters of P2X2-GFP fluorescence appeared to form. This effect was not dependent on external $\mathrm{Ca}^{2+}$, and beading also occurred with the $\mathrm{P} 2 \mathrm{X} 2$ receptor agonist, 2meSATP. Preincubation with the antagonists, PPADS or suramin, completely abolished the beading effect (results not shown). Previously, application of glutamate to cortical neurons has been shown to cause varicosity formation in dendrites as a result of injury caused by excessive influx of $\mathrm{Na}^{+}$(Hasbani et al., 1998). To determine whether ATP caused a change in the morphology of the dendrites themselves, we stained with an antibody to the dendritic protein, MAP-2. In control cells, MAP-2 staining was uniform along the length of the processes, whereas in cells exposed to agonist, it occurred in beads that corresponded exactly with the beads of P2X2-GFP fluorescence (Fig. 5D,E). Thus, our results suggest that the redistribution of $\mathrm{P} 2 \mathrm{X} 2-\mathrm{GFP}$ reflects a change in the morphology of the dendrites and that P2X2-GFP is simply reporting this change.

\section{Dynamin-dependent endocytosis of P2X4 receptors}

To investigate the mechanism of $\mathrm{P} 2 \mathrm{X} 4$ receptor internalization, we tested the effects of a dominant-negative mutant form of dynamin-1 [dynamin-1(K44A)] on the distribution of the receptor. The effect of inhibiting dynamin-dependent endocytosis with this mutant was essentially to cause the distribution of P2X4 receptors to become similar to that of $\mathrm{P} 2 \mathrm{X} 2$ receptors. Coexpression of dynamin-1(K44A), but not wild-type dynamin-1, changed the distribution from punctate to uniform, suggesting that internalization of receptors into endosomal compartments was inhibited (Fig. $6 A, B$ ). It also caused a dramatic increase in the expression of P2X4(AU5) receptors at the cell surface, as shown by labeling with extracellular anti-AU5 (Fig. $6 C-F$ ). Consistent with the increase in surface immunofluorescence, the ATP-evoked whole-cell currents recorded from P2X4-GFP-transfected neurons were also significantly increased $(p<0.01)$ by coexpression of dynamin-1(K44A) (Fig. 6G). Nevertheless, the current densities of P2X4-transfected neurons after coexpression with dynamin-1(K44A) were still approximately fourfold less than for $\mathrm{P} 2 \mathrm{X} 2$-transfected neurons. One reason for this is that the singlechannel conductance is more than twofold higher for P2X2 than for P2X4 receptors (9 vs $21 \mathrm{pS}$; Evans, 1996). Not surprisingly, coexpressing dynamin-1(K44A) with P2X2-GFP had no obvious effect on either the distribution of the receptor or on the amplitude of the ATP-evoked whole-cell currents (Fig. 6H). Thus, similar to other ligand-gated ion channels, the internalization of $\mathrm{P} 2 \mathrm{X} 4$ receptors involves a dynamin-dependent mechanism.

\section{P2X receptors act presynaptically to regulate glutamatergic transmission}

Other ligand-gated ion channels, such as the AMPA and $\mathrm{GABA}_{\mathrm{A}}$ receptors, cycle into and out of the postsynaptic membrane. Within the adult rat $\mathrm{OB}, \mathrm{P} 2 \mathrm{X} 4$ immunoreactivity was shown to be associated with both dendrites and axon terminals, suggesting a presynaptic and postsynaptic role. In transfected mitral cells, where the dendrites and axon were clearly distinguishable, both $\mathrm{P} 2 \mathrm{X} 2$ and $\mathrm{P} 2 \mathrm{X} 4$ receptors were present throughout the cell, and there was no indication of specific targeting to either only somatodendritic or axonal compartments. OB neurons in situ have dendrodendritic reciprocal synapses, and therefore both presynaptic and postsynaptic structures are present within the dendrites. Some of the puncta of P2X4-GFP receptors colocalized with synaptobrevin-immunopositive structures, suggesting that receptor clusters were in the vicinity of synapses (Fig. $7 A$ ). We looked 
A

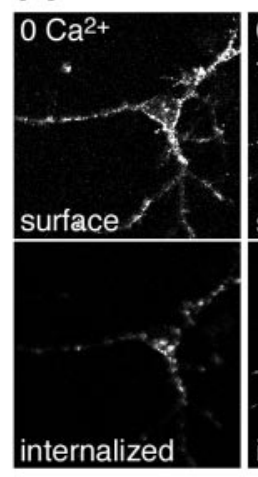

Figure 5. The effect of ATP on trafficking of P2X receptors in neurons. $A-C$, ATP-dependent P2X4(AU5) and P2X2(FLAG) receptor internalization was measured by livelabeling neurons for $30 \mathrm{~min}$ at $37^{\circ} \mathrm{C}$ with anti-AU5 and anti-FLAG, respectively. Cell surface and internalized receptors were stained after $15 \mathrm{~min}$ incubation in control or $\mathrm{Ca}^{2+}$-free solution with or without ATP $(100 \mu \mathrm{M})(A) . B, C$, Quantification of P2X4(AU5) and P2X2(FLAG) receptor internalization. Histograms show the internalized fluorescence as a fraction of total labeled (surface plus internalized) fluorescence, normalized to control cells $(n=7-29$ neurons for each condition). ATP-dependent $(100 \mu \mathrm{M})$ internalization of P2X4(AU5) receptors is independent of extracellular $\mathrm{Ca}^{2+}(B) . D, E$, Neurons expressing P2X2-GFP receptors were stained with anti-MAP-2. Application of ATP $(100 \mu \mathrm{M})$ causes dendritic injury in P2X2-GFP transfected neurons.
C

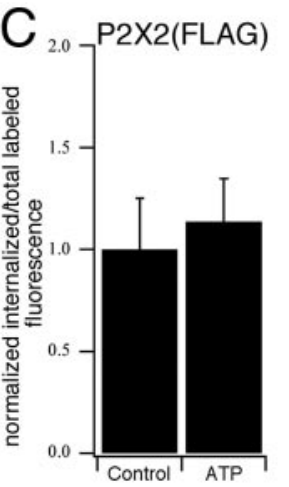

B
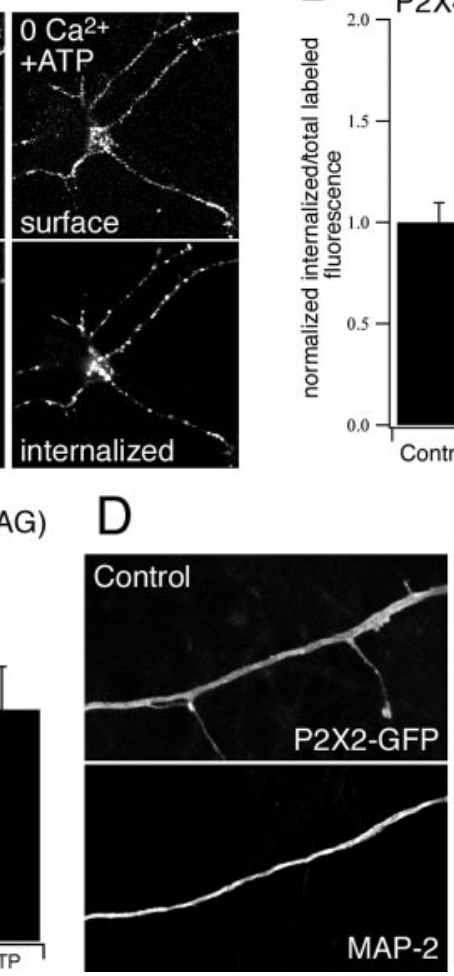

$\mathrm{P} 2 \times 4(\mathrm{AU} 5)$

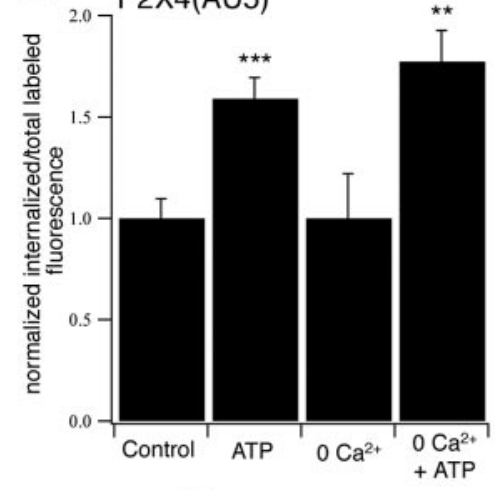

E

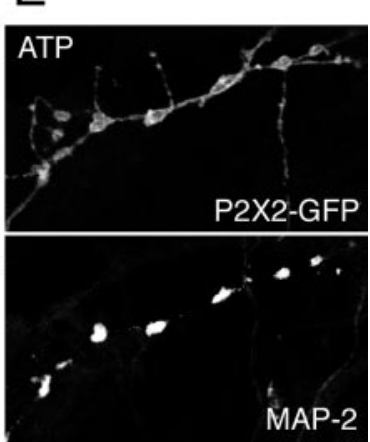

for a presynaptic action of $\mathrm{P} 2 \mathrm{X} 2$ and $\mathrm{P} 2 \mathrm{X} 4$ receptors by recording miniature postsynaptic currents from neighboring untransfected neurons in the presence of TTX $(1 \mu \mathrm{M})$. Localized applications of ATP $(100 \mu \mathrm{M})$ to the processes of P2X4-transfected neurons evoked an increase in the frequency of mEPSCs ( 9 of 25 cells tested) (Fig. $7 B$ ). The mean increase in frequency was $522 \pm 55 \%$. These mEPSCs were completely blocked by CNQX $(10 \mu \mathrm{M} ; n=$ 3 ), indicating that they were mediated by AMPA-kainate receptors (Fig. $7 C$ ), whereas application of bicuculline had no effect. Similarly in neurons transfected with P2X2-GFP, we recorded ATP evoked changes in mEPSC frequency in response to ATP (five of nine cells tested). Control recordings were performed on neurons that neighbored untransfected neurons. No increase in the frequency of mPSCs in response to application of ATP was observed $(n=32)$, suggesting that the observed increase in mEPSC frequency was not attributable to activation of endogenous receptors.

\section{Endogenous P2X receptors in dissociated OB neurons}

Although P2X4 receptor expression is reported to be highest in the $\mathrm{OB}$ of adult rat, as compared with other brain regions (Lê et al., 1998), in cultured OB neurons of rat neonates $\geq 7$ DIV, which was the minimal period before transfection, we failed to detect any $\mathrm{P} 2 \mathrm{X} 4$ or P2X2 immunoreactivity (Fig. $8 C$ ). In contrast, dissociated neurons plated for only $4 \mathrm{hr}$ showed $\mathrm{P} 2 \mathrm{X} 4$ immunoreactivity that was punctate and appeared to be in intracellular compartments (Fig. 8A,B). Thus the distribution of endogenous receptors in freshly plated $\mathrm{OB}$ neurons resembles that of heterologously expressed $\mathrm{P} 2 \mathrm{X} 4$ receptors, as well as neurons in the intact $\mathrm{OB}$, where they were described as "consistently intracellular, in the form of small intracytoplasmic hot spots" (Lê et al., 1998). However in culture, the expression of endogenous P2X4 appears to be downregulated (Fig. 8C).

Previous studies have shown that $\mathrm{OB}$ neurons of adult rat also express P2X2 receptors (Kanjhan et al., 1999). However, in both freshly plated and cultured OB neurons of rat neonates, P2X2 receptor expression was below the level of detection, suggesting that the expression of $\mathrm{P} 2 \mathrm{X} 2$ is upregulated during development. Similarly, cultured hippocampal neurons from embryonic rats show no ATP-evoked responses, whereas hippocampal neurons in brain slices from adult rat have robust $\mathrm{P} 2 \mathrm{X}$-mediated currents (Khakh et al., 1999).

\section{P2X4/6 heteromeric receptors in HEK293 cells have a distribution similar to that of P2X4 homomeric receptors}

The endogenous receptors may be heteromeric or homomeric complexes. P2X4 forms heteromeric receptors with $\mathrm{P} 2 \mathrm{X} 6$ but not with P2X2, and in the CNS, P2X4 and P2X6 have an overlapping distribution (Khakh et al., 2001b; Rubio and Soto, 2001). To test whether the distribution of the heteromer is determined by the P2X4 subunit, we expressed P2X6-GFP alone and together with P2X4 in HEK293 cells. P2X6 does not form functional homomeric receptors ( $n=3$; Khakh et al., 2001b), and P2X6-GFP expression was low compared with that of either P2X2-GFP or P2X4-GFP. P2X6-GFP fluorescence was diffusely distributed within the cell and colocalized with calreticulin, a marker for the endoplasmic reticulum, suggesting that the majority of receptors were not delivered to the cell surface (Fig. 9A). In contrast, P2X6-GFP coexpressed with P2X4 had a punctate distribution that resembled that of homomeric $\mathrm{P} 2 \mathrm{X} 4$ receptors. It colocalized with anti-EEA1 and anti-P2X4 immunoreactivity (Fig. 9B). We also coexpressed P2X2-GFP with P2X4 as a control, to test whether the coexpression of subunits might influence the distribution of each other, even without their coassembly. In fact we saw no change in the distribution of either receptor (Fig. 9C). P2X2-GFP receptors were at the periphery of the cell, whereas $\mathrm{P} 2 \mathrm{X} 4$ receptors were predominantly in intracellular puncta, and 

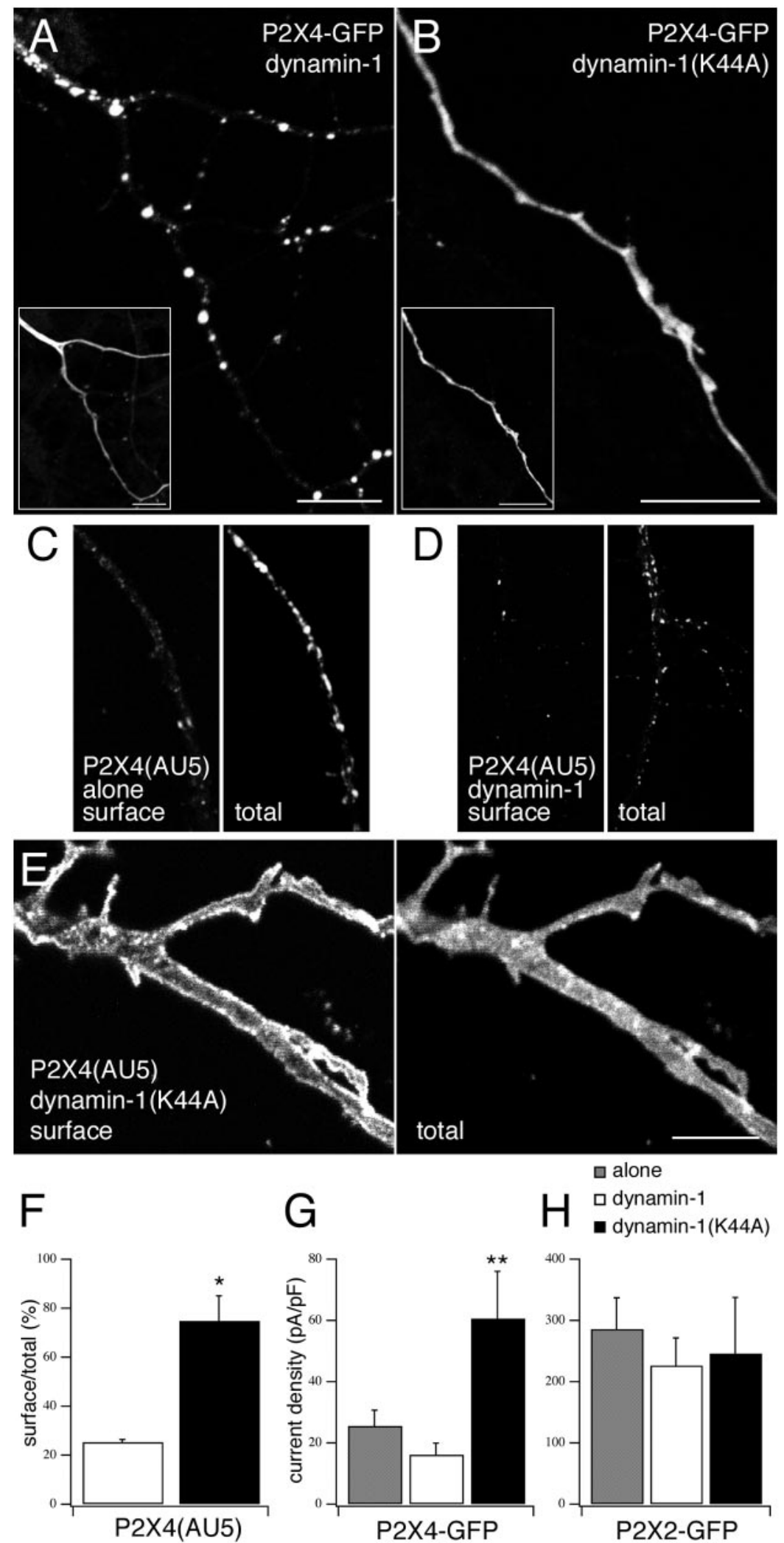

P2X4-GFP
H adynamin-1

- dynamin-1(K44A)

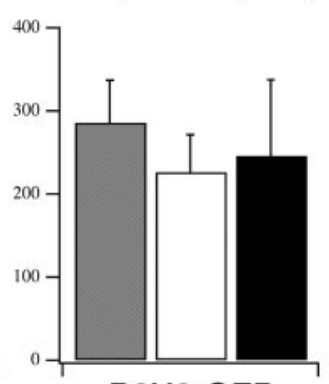

P2X2-GFP

Figure 6. Trafficking of $\mathrm{P} 2 \mathrm{X} 4$ is dynamin-dependent. $A, B$, Confocal images of P2X4-GFP coexpressed with either wildtype $(A)$ or dominant-negative $(B)$ dynamin-1. Inset images show detection of the coexpressed dynamin-1 constructs using anti-HA/Cy3. $C-E$, Confocal images to show neurons expressing P2X4(AU5) alone $(C)$ or with either wild-type dynamin-1 $(D)$ or dynamin-1(K44A) $(E)$ were immunostained for cell surface receptors (anti-AU5/Cy3 before permeabilization) and total receptor (anti-P2X4/FITC after permeabilization). Scale bars, $10 \mu \mathrm{m}$. $F$, Quantification of surface versus total receptor in neurons coexpressing P2X4(AU5) and either dynamin-1 or dynamin-1(K44A) $(n=$ 3 neurons for both condition). $G, H$, Histograms of the mean whole-cell current densities after application of ATP (100 $\mu \mathrm{M})$ in neurons expressing either P2X4-GFP $(G)$ or P2X2GFP $(H)$ alone (shaded) or coexpressed with either dynamin-1 (white bars) or dynamin-1(K44A) (black bars) $(n=5-15$ neurons for each condition).

there was no indication that $\mathrm{P} 2 \mathrm{X} 2$ receptors were endocytosed along with $\mathrm{P} 2 \mathrm{X} 4$ receptors, suggesting that they might be excluded from sites of internalization. This result also confirms that the differences in the trafficking of $\mathrm{P} 2 \mathrm{X} 2$ and $\mathrm{P} 2 \mathrm{X} 4$ receptors cannot be explained by differences in their levels of expression.

\section{DISCUSSION}

These results demonstrate that two subtypes of purinoceptor, $\mathrm{P} 2 \mathrm{X} 2$ and $\mathrm{P} 2 \mathrm{X} 4$, are trafficked in distinct ways in cultured neurons. Whereas $\mathrm{P} 2 \mathrm{X} 2$ receptors in the plasma membrane were 
A

Figure 7. Presynaptic function of $\mathrm{P} 2 \mathrm{X} 4$ receptors. $A$, Confocal image to show the colocalization of P2X4-GFP puncta (left panel) with anti-synaptobrevin/Cy-3 immunofluorescence (right panel). Arrowheads indicate areas of colocalization. Scale bar, 10 $\mu \mathrm{m}$. $B$, Increase in the frequency of mEPSCs recorded from an untransfected neuron, after application of ATP to the process of a neighboring transfected neuron, in the presence of TTX $(1 \mu \mathrm{M})$. The holding potential was $-40 \mathrm{mV}$. $C$, The ATP-mediated increase in the frequency of mEPSCs was reversibly blocked by CNQX $(10 \mu \mathrm{M})$.
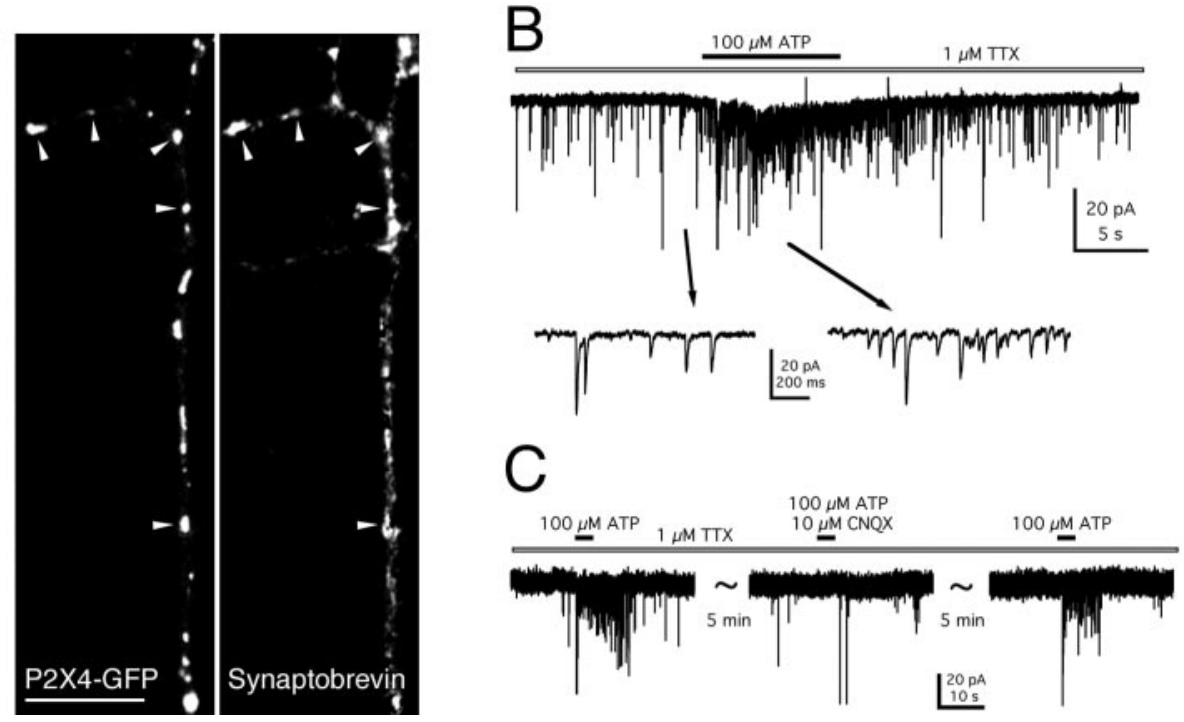
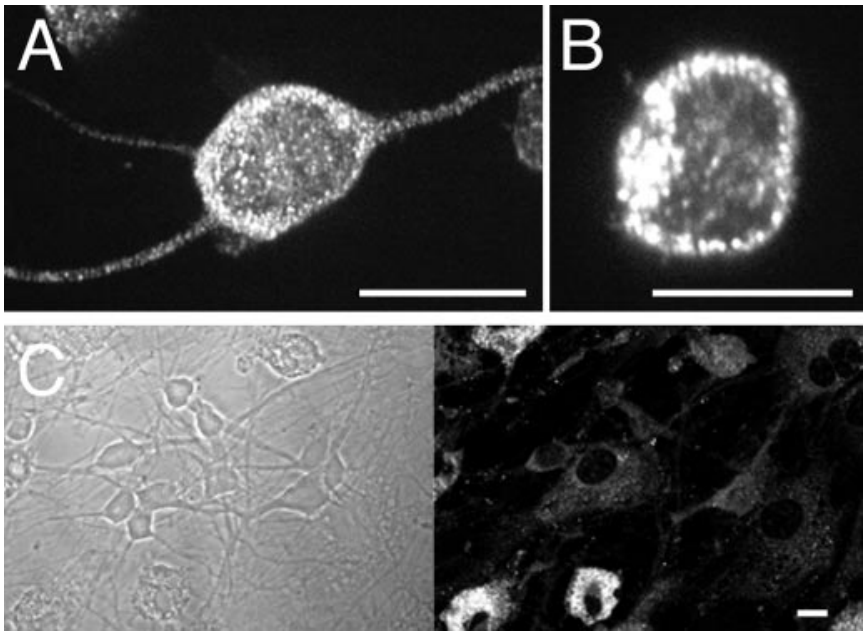

Figure 8. Endogenous $\mathrm{P} 2 \mathrm{X} 4$ receptors have a punctate distribution. $A, B$, Subcellular distribution of endogenous P2X4 in freshly plated OB neurons (4 hr in vitro). $C, \mathrm{P} 2 \mathrm{X} 4$ immunoreactivity in $\mathrm{OB}$ neurons was downregulated after 7 DIV, whereas microglia remained P2X4-positive. Cells were stained using anti-P2X4/FITC. Scale bars, $10 \mu \mathrm{m}$.

relatively stable, $\mathrm{P} 2 \mathrm{X} 4$ receptors were rapidly retrieved by a dynamin-dependent mechanism and subsequently cycled back to the plasma membrane. Binding of ATP to the P2X4 receptor stimulated its internalization, but ATP did not affect retrieval of $\mathrm{P} 2 \mathrm{X} 2$ receptors. Within $\mathrm{P} 2 \mathrm{X} 4 / 6$ heteromeric complexes, $\mathrm{P} 2 \mathrm{X} 4$ played a dominant role in determining the subcellular distribution of the receptor. Our observation that $\mathrm{P} 2 \mathrm{X}$ receptors can act presynaptically to enhance the release of glutamate suggests that the regulated cycling of $\mathrm{P} 2 \mathrm{X} 4$-containing receptors might provide a mechanism for modulation of receptor density at presynaptic sites.

\section{The P2X4 subunit determines the distribution of heteromeric receptors}

The distribution of $\mathrm{P} 2 \mathrm{X} 4 / 6$ heteromers resembled that of the $\mathrm{P} 2 \mathrm{X} 4$ homomeric receptors, suggesting that the $\mathrm{P} 2 \mathrm{X} 4$ subunit is dominant in determining the trafficking of the heteromer. Similarly, for AMPA receptors, there is diversity of trafficking that is subunit-dependent, and for heteromeric complexes it appears that one subunit will play a dominant role in determining the insertion and retrieval of receptors from the postsynaptic membrane (Sheng and Lee, 2001; Shi et al., 2001). There are several regions of the CNS where P2X2, P2X4, and P2X6 have been shown to be coexpressed, and therefore within neurons the endogenous $\mathrm{P} 2 \mathrm{X}$ receptor population may consist of homomers and heteromers (Norenberg and Illes, 2000). However, even in regions where P2X4 mRNA is abundant and P2X4 protein expression was detected (e.g., in hippocampal neurons), neuronal P2X-mediated currents do not resemble homomeric $\mathrm{P} 2 \mathrm{X} 4$ receptor currents or even $\mathrm{P} 2 \mathrm{X} 4 / 6$ heteromers with regards to their pharmacological properties (Khakh et al., 2001b; Rubio and Soto, 2001). One possible explanation is that there are no $\mathrm{P} 2 \mathrm{X} 4$ homomers or $\mathrm{P} 2 \mathrm{X} 4 / 6$ heteromers within the receptor population. However, our results offer a different possible explanation. The P2X4-containing receptors are predominantly in intracellular compartments and are upregulated at the cell surface only in response to certain physiological or pathological stimuli, whereas receptors with P2X2 subunits are more stable at the surface, and thus mediate the majority of the ATP-evoked response. Key questions to be addressed in future studies are how the cycling of P2X4 into and out of the plasma membrane is regulated and what are the important physiological regulators other than ATP?

\section{Regulation of receptor trafficking by ATP}

Application of ATP enhanced the rate of $\mathrm{P} 2 \mathrm{X} 4$ receptor internalization. Despite the fact that $\mathrm{P} 2 \mathrm{X} 4$ receptors are highly permeable to calcium (Soto et al., 1996), this effect of ATP occurred in the absence of extracellular calcium, suggesting that the increase might be caused by an agonist-induced conformational change in the receptor promoting an interaction with components of the endocytotic machinery. However, the molecular interactions between P2X4 and endocytotic proteins have yet to be characterized. Depending on the rate at which internalized receptors are subsequently reinserted into the plasma membrane, increased internalization might lead to a reduction in the size of the response to multiple applications of ATP. Ennion and Evans (2001) showed that for P2X1 receptors in smooth muscle, the ATP evoked increase in internalization was matched by an increase in the rate of reinsertion, and as a consequence the number of receptors at the surface remained fairly constant. They therefore concluded that after an application of ATP to P2X1 recep- 

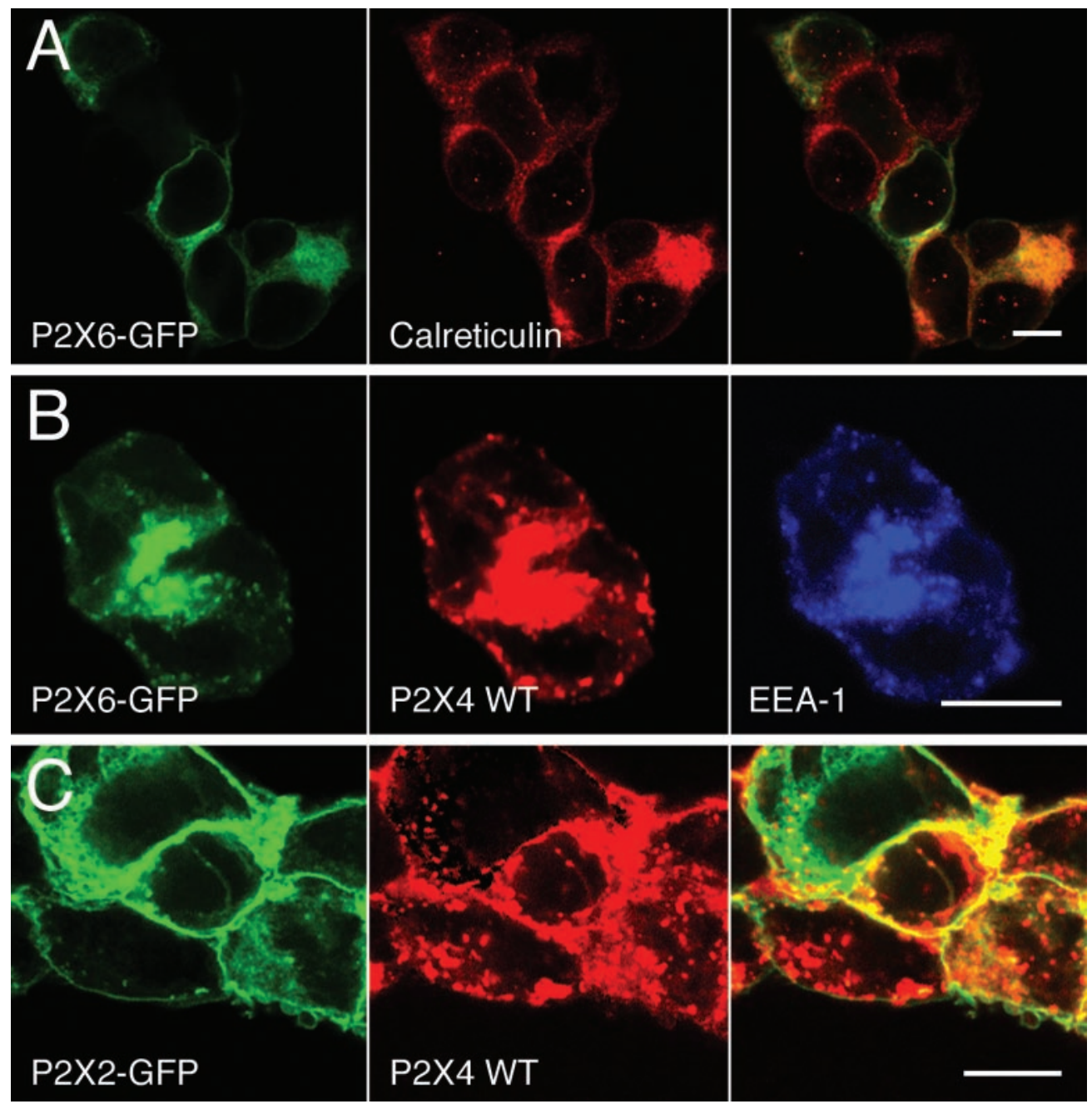

Figure 9. P2X4 determines heteromeric $\mathrm{P} 2 \mathrm{X} 4 / 6$ receptor trafficking. $A$, Confocal image to show the colocalization between P2X6-GFP and the ER marker calreticulin. $B$, Coexpression of P2X6-GFP with P2X4 WT and their colocalization with the early endosomal marker EEA-1. $C$, Coexpression of P2X2-GFP and P2X4 WT in HEK293 cells. Cells were stained using anti-calreticulin/Cy3 $(A)$ or anti-P2X4/Cy5 and anti-EEA-1/Cy3 $(B)$ and anti-P2X4/ TRITC $(C)$. Right panels show overlaid images $(A, C)$. Scale bars, $10 \mu \mathrm{m}$.

tors, the rate of recovery from desensitization was not limited by the rate at which receptors reinserted into the plasma membrane.

Application of ATP to neurons transfected with P2X2-GFP caused varicosities to appear along dendrites. Application of glutamate to cortical neurons leads to a similar change in the morphology, believed to be a pathological response caused by excessive cation influx (Faddis et al., 1997; Hasbani et al., 1998). It has been suggested that the "beading" of P2X2-GFP fluorescence in response to ATP might additionally reflect a redistribution of P2X2-GFP receptors within the membrane (Khakh et al., 2001a). A change in the surface distribution of receptors is difficult to quantify when the morphology of dendrites are changing, but the beading of P2X2-GFP fluorescence in response to ATP that we observed was exactly mimicked by changes in MAP-2 immunofluorescence (Fig. 5E). Thus, the simplest explanation for the change in the pattern of P2X2-GFP fluorescence is the obvious change in dendritic morphology rather than movements of receptors within the plasma membrane.

\section{Cycling of synaptic ionotropic receptors}

The cycling of receptors into and out of the plasma membrane provides a means of modulating receptor density by regulation of internalization or insertion rates (Burrone and Murthy, 2001). AMPA and $\mathrm{GABA}_{\mathrm{A}}$ receptors undergo both constitutive and regulated cycling, and this has been shown to be important in modulating excitatory and inhibitory transmission (Carroll et al.,
2001; Moss and Smart, 2001). In contrast, NMDA receptors are more stable at the postsynaptic membrane, not because they lack a suitable endocytotic motif, but because they are stabilized via an interaction with PDZ domain proteins (Roche et al., 2001). The relative stability of $\mathrm{P} 2 \mathrm{X} 2$ receptors might similarly reflect an interaction with some other protein or the lack of a determinant for rapid internalization present in P2X4. However, no suitable $\mathrm{P} 2 \mathrm{X} 2$ receptor binding partners have been identified as yet.

The physiological role of $\mathrm{P} 2 \mathrm{X}$ receptors in central and peripheral neurons is not well established. However, there are several examples of synapses where $\mathrm{P} 2 \mathrm{X}$ receptors act presynaptically to increase neurotransmitter release. These include the first sensory synapse in the spinal cord (Gu and MacDermott, 1997; Nakatsuka and $\mathrm{Gu}, 2001$ ), the synapse between brainstem and trigeminal neurons (Khakh and Henderson, 1998), and synapses in the nucleus tractus solitarii (Kato and Shigetomi, 2001). Our results suggest that heterologously expressed $\mathrm{P} 2 \mathrm{X}$ receptors can also act presynaptically to regulate the release of glutamate. The regulation of $\mathrm{P} 2 \mathrm{X}$ receptor density at presynaptic sites might therefore represent a mechanism for the modulation of synaptic transmission.

\section{REFERENCES}

Beattie EC, Carroll RC, Yu X, Morishita W, Yasuda H, von Zastrow M, Malenka RC (2000) Regulation of AMPA receptor endocytosis by a signaling mechanism shared with LTD. Nat Neurosci 3:1291-1300. 
Burrone J, Murthy VN (2001) Synaptic plasticity: rush hour traffic in the AMPA lanes. Curr Biol 11:R274-R277.

Carroll RC, Beattie EC, Xia HH, Luscher C, Altschuler Y, Nicoll RA, Malenka RC, von Zastrow M (1999) Dynamin-dependent endocytosis of ionotropic glutamate receptors. Proc Natl Acad Sci USA 96:14112-14117.

Carroll RC, Beattie EC, von Zastrow M, Malenka RC (2001) Role of AMPA receptor endocytosis in synaptic plasticity. Nat Rev Neurosci $2: 315-324$

Collo G, North RA, Kawashima E, Merlo-Pich E, Neidhart S, Surprenant A, Buell G (1996) Cloning of P2X5 and P2X6 receptors and the distribution and properties of an extended family of ATP-gated ion channels. J Neurosci 16:2495-2507.

Dutton JL, Poronnik P, Li GH, Holding CA, Worthington RA, Vandenberg RJ, Cook DI, Barden JA, Bennett MR (2000) P2X1 receptor membrane redistribution and down-regulation visualized by using receptor-coupled green fluorescent protein chimeras. Neuropharmacology 39:2054-2066.

Ehlers MD (2000) Reinsertion or degradation of AMPA receptors determined by activity-dependent endocytic sorting. Neuron 28:511-525.

Ennion SJ, Evans RJ (2001) Agonist-stimulated internalisation of the ligand-gated ion channel $\mathrm{P} 2 \mathrm{X}(1)$ in rat vas deferens. FEBS Lett 489:154-158

Evans RJ (1996) Single channel properties of ATP-gated cation channels (P2X receptors) heterologously expressed in Chinese hamster ovary cells. Neurosci Lett 212:212-214.

Faddis BT, Hasbani MJ, Goldberg MP (1997) Calpain activation contributes to dendritic remodeling after brief excitotoxic injury in vitro. J Neurosci 17:951-959.

Gu JG, MacDermott AB (1997) Activation of ATP P2X receptors elicits glutamate release from sensory neuron synapses. Nature 389:749-753.

Hamill OP, Marty A, Neher E, Sakmann B, Sigworth FJ (1981) Improved patch-clamp techniques for high-resolution current recording from cells and cell-free membrane patches. Pflügers Arch 391:85-100.

Hasbani MJ, Hyrc KL, Faddis BT, Romano C, Goldberg MP (1998) Distinct roles for sodium, chloride, and calcium in excitotoxic dendritic injury and recovery. Exp Neurol 154:241-258.

Hugel S, Schlichter R (2000) Presynaptic P2X receptors facilitate inhibitory GABAergic transmission between cultured rat spinal cord dorsal horn neurons. J Neurosci 20:2121-2130.

Kanjhan R, Housley GD, Burton LD, Christie DL, Kippenberger A, Thorne PR, Luo L, Ryan AF (1999) Distribution of the P2X2 receptor subunit of the ATP-gated ion channels in the rat central nervous system. J Comp Neurol 407:11-32.

Kato F, Shigetomi E (2001) Distinct modulation of evoked and spontaneous EPSCs by purinoceptors in the nucleus tractus solitarii of the rat. J Physiol (Lond) 530:469-486.

Khakh BS (2001) Molecular physiology of P2X receptors and ATP signalling at synapses. Nat Rev Neurosci 2:165-174.

Khakh BS, Henderson G (1998) ATP receptor-mediated enhancement of fast excitatory neurotransmitter release in the brain. Mol Pharmacol 54:372-378.

Khakh BS, Proctor WR, Dunwiddie TV, Labarca C, Lester HA (1999) Allosteric control of gating and kinetics at P2X(4) receptor channels. J Neurosci 19:7289-7299.

Khakh BS, Smith WB, Chiu CS, Ju DH, Davidson N, Lester HA (2001a) Activation-dependent changes in receptor distribution and dendritic morphology in hippocampal neurons expressing P2X2-green fluorescent protein receptors. Proc Natl Acad Sci USA 98:5288-5293.

Khakh BS, Burnstock G, Kennedy C, King BF, North RA, Seguela P, Voigt M, Humphrey PP (2001b) International union of pharmacology. XXIV Current status of the nomenclature and properties of P2X receptors and their subunits Pharmacol Rev 53:107-118.

Kittler JT, Delmas P, Jovanovic JN, Brown DA, Smart TG, Moss SJ (2000) Constitutive endocytosis of GABAA receptors by an association with the adaptin AP2 complex modulates inhibitory synaptic currents in hippocampal neurons. J Neurosci 20:7972-7977.

Koizumi S, Bootman MD, Bobanovic LK, Schell MJ, Berridge MJ, Lipp
$\mathrm{P}$ (1999) Characterization of elementary $\mathrm{Ca}^{2+}$ release signals in NGF-differentiated PC12 cells and hippocampal neurons. Neuron 22:125-137.

Kozak M (1987) An analysis of 5'-noncoding sequences from 699 vertebrate messenger RNAs. Nucleic Acids Res 15:8125-8148.

Lê KT, Villeneuve P, Ramjaun AR, McPherson PS, Beaudet A, Seguela P (1998) Sensory presynaptic and widespread somatodendritic immunolocalization of central ionotropic P2X ATP receptors. Neuroscience 83:177-190.

Li GH, Lee EM, Blair D, Holding C, Poronnik P, Cook DI, Barden JA, Bennett MR (2000) The distribution of P2X receptor clusters on individual neurons in sympathetic ganglia and their redistribution on agonist activation. J Biol Chem 275:29107-29112.

Lin JW, Ju W, Foster K, Lee SH, Ahmadian G, Wyszynski M, Wang YT, Sheng M (2000) Distinct molecular mechanisms and divergent endocytotic pathways of AMPA receptors internalization. Nat Neurosci 3:1282-1290.

Lissin DV, Gomperts SN, Carroll RC, Christine CW, Kalman D, Kitamura M, Hardy S, Nicoll RA, Malenka RC, von Zastrow M (1998) Activity differentially regulates the surface expression of synaptic AMPA and NMDA glutamate receptors. Proc Natl Acad Sci USA 95:7097-7102.

Man HY, Lin JW, Ju WH, Ahmadian G, Liu LD, Becker LE, Sheng M, Wang YT (2000) Regulation of AMPA receptor-mediated synaptic transmission by clathrin-dependent receptor internalization. Neuron 25:649-662

Marsh M, McMahon HT (1999) The structural era of endocytosis. Science 285:215-220.

Moss SJ, Smart TG (2001) Constructing inhibitory synapses. Nat Rev Neurosci 2:240-250.

Nakatsuka T, Gu JG (2001) ATP P2X receptor-mediated enhancement of glutamate release and evoked EPSCs in dorsal horn neurons of the rat spinal cord. J Neurosci 21:6522-6531.

Norenberg W, Illes P (2000) Neuronal P2X receptors: localisation and functional properties. Naunyn Schmiedebergs Arch Pharmacol 362:324-339.

Roche KW, Standley S, McCallum J, Dune LC, Ehlers MD, Wenthold RJ (2001) Molecular determinants of NMDA receptor internalization. Nat Neurosci 4:794-802.

Rubio ME, Soto F (2001) Distinct Localization of P2X receptors at excitatory postsynaptic specializations. J Neurosci 21:641-653.

Sheng M, Lee SH (2001) AMPA receptor trafficking and the control of synaptic transmission. Cell 105:825-828.

Shi SH, Hayashi Y, Esteban JA, Malinow R (2001) Subunit-specific rules governing AMPA receptor trafficking to synapses in hippocampal pyramidal neurons. Cell 105:331-343.

Soto F, Garcia-Guzman M, Gomez-Hernandez JM, Hollmann M, Karschin C, Stuhmer W (1996) P2X4: an ATP-activated ionotropic receptor cloned from rat brain. Proc Natl Acad Sci USA 93:3684-3688.

Stoop R, Thomas S, Rassendren F, Kawashima E, Buell G, Surprenant A, North RA (1999) Contribution of individual subunits to the multimeric $\mathrm{P} 2 \mathrm{X}(2)$ receptor: estimates based on methanethiosulfonate block at T336C. Mol Pharmacol 56:973-981.

Torres GE, Egan TM, Voigt MM (1999) Hetero-oligomeric assembly of $\mathrm{P} 2 \mathrm{X}$ receptor subunits. Specificities exist with regard to possible partners J Biol Chem 274:6653-6659.

Turrigiano GG (2000) AMPA receptors unbound: Membrane cycling and synaptic plasticity. Neuron 26:5-8.

Vulchanova L, Riedl MS, Shuster SJ, Buell G, Surprenant A, North RA, Elde R (1997) Immunohistochemical study of the P2X2 and P2X3 receptor subunits in rat, monkey sensory neurons and their central terminals. Neuropharmacology 36:1229-1242.

Wang YT, Linden DJ (2000) Expression of cerebellar long-term depression requires postsynaptic clathrin-mediated endocytosis. Neuron 25:635-647.

Xia Z, Dudek H, Miranti CK, Greenberg ME (1996) Calcium influx via the NMDA receptor induces immediate early gene transcription by a MAP kinase/ERK-dependent mechanism. J Neurosci 16:5425-5436. 